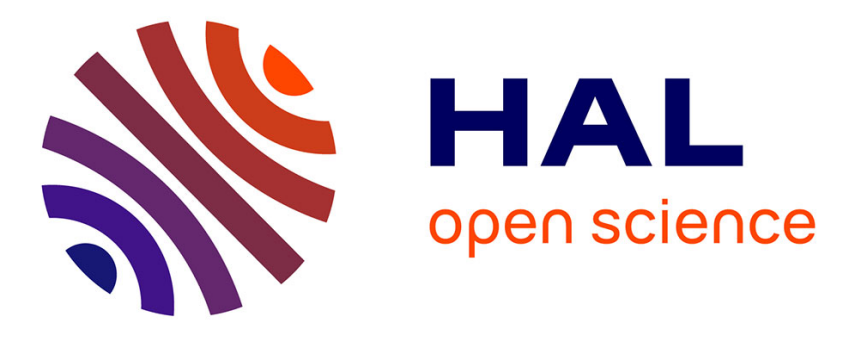

\title{
Variation of organic carbon and nitrate with river flow within an oceanic regime in a rural area and potential impacts for drinking water production
}

Estelle Baurès, I. Delpla, S. Merel, Marie-Florence Thomas, A.-V. Jung, Olivier Thomas

\section{To cite this version:}

Estelle Baurès, I. Delpla, S. Merel, Marie-Florence Thomas, A.-V. Jung, et al.. Variation of organic carbon and nitrate with river flow within an oceanic regime in a rural area and potential impacts for drinking water production. Journal of Hydrology, 2013, 477, pp.86-93. 10.1016/j.jhydrol.2012.11.006 . hal-00878009

\section{HAL Id: hal-00878009 \\ https://hal.science/hal-00878009}

Submitted on 6 Jan 2020

HAL is a multi-disciplinary open access archive for the deposit and dissemination of scientific research documents, whether they are published or not. The documents may come from teaching and research institutions in France or abroad, or from public or private research centers.
L'archive ouverte pluridisciplinaire $\mathbf{H A L}$, est destinée au dépôt et à la diffusion de documents scientifiques de niveau recherche, publiés ou non, émanant des établissements d'enseignement et de recherche français ou étrangers, des laboratoires publics ou privés. 


\title{
Variation of organic carbon and nitrate with river flow within an oceanic regime in a rural area and potential impacts for drinking water production
}

\author{
E. Baurès ${ }^{\mathrm{a}, \mathrm{b}, *}$, I. Delpla ${ }^{\mathrm{a}, \mathrm{b}}, \mathrm{S}$. Merel ${ }^{\mathrm{c}}$, M.-F. Thomas ${ }^{\mathrm{d}}$, A.-V. Jung ${ }^{\mathrm{a}, \mathrm{b}, \mathrm{d}}$, O. Thomas ${ }^{\mathrm{a}, \mathrm{b}}$ \\ ${ }^{a}$ Environment and Health Research laboratory (LERES), EHESP School of Public Health, Avenue du Professeur Léon Bernard, CS 74312,35043 Rennes Cedex, France \\ ${ }^{\mathrm{b}}$ Inserm, U 1085 Institute of Research in Environmental and Occupational Health (IRSET), Avenue du Professeur Léon Bernard, CS 74312,35043 Rennes Cedex, France \\ ${ }^{\mathrm{c}}$ Department of Chemical and Environmental Engineering, University of Arizona, 1133 James E. Rogers Way, Tucson, AZ 85721, United States \\ ${ }^{\mathrm{d}}$ School of Environmental Engineering (EME), Campus de Ker Lann, Avenue Robert Schumann, 35170 Bruz, France
}

Over the last two decades, climate change has become a major environmental and public health concern due to the increase of the mean temperature on the Earth and its consequences on extreme meteorolog-ical events such as floods and droughts. These events induce very low or very high river flows that may impair surface water quality, and therefore result in potential health impacts when used for drinking water production. The present study aims at assessing the impact of hydrologic regime on surface water quality with a particular emphasis on total organic carbon (TOC) and nitrate. Water quality data from three French rivers acquired over a 27 years period, from January 1983 to December 2009, show the influ-ence of extreme flows. Variation in TOC and nitrate concentrations showed opposite patterns for the whole range of flow rate (from less than $10 \%$ up to more than $100 \%$ of the mean flow). Regarding fluxes, TOC increased continuously with flow rate while nitrate was stable for very high discharges. The C/N ratio expressed from TOC and nitrate concentrations showed high values for extreme flows and particularly for very low flow rates, generally in summer, where nitrate is assimilated by biomass. Considering TOC and nitrate fluxes, it is confirmed that the worst situations were encountered for very high flow rates, namely for TOC exportation during surface runoff which was related to heavy rains or floods. These findings are of great importance with regard to the adaptation for drinking water treatment in facing extreme hydrolog-ical conditions, of which the frequency is increasing with climate change.

\section{Introduction}

At a river basin scale, any water management actions should take into account water quantity and quality variations.

This is of primary importance within the frame of water safety plans implementation when surface water is used for drinking water supply after treatment. Regarding water quality variation, a lot of data is available worldwide primarily for the main physico-chemical parameters, nutrients and some micropollutants. While the majority of recent research has focused on the contamination of emerging substances like pharmaceuticals, an understanding of the relationship between basic parameters of water quality like organic carbon and nitrate is still relevant today (Taylor and Townsend, 2010). These authors showed from the

* Corresponding author at: Environment and Health Research laboratory (LERES), EHESP School of Public Health, Avenue du Professeur Léon Bernard, CS 74312, 35043 Rennes Cedex, France. Tel.: + 332990229 19; fax: + 33299022929 .

E-mail addresses: estelle.baures@ehesp.fr (E. Baurès), ianis.delpla@ehesp.fr (I. Delpla), sylvain.merel@gmail.com (S. Merel), marieflorencethomas@ecole-eme.com (M.-F. Thomas), audevaleriejung@ecole-eme.com (A.-V. Jung), olivier.thomas@ ehesp.fr (O. Thomas). exploitation of thousands of data points that there are negative nonlinear relationships between nitrate and organic carbon concentrations for a hydrologic continuum from soils, streams, lakes, and oceans. Concerning rivers in rural areas, whose water can be treated for supply systems, mostly of small size, the knowledge of water quality variation should be documented in the risk assessment step of water safety plans. Climate change impacts with a possible increase in extreme weather events (floods and droughts), may lead to the modification of hydrologic regimes of rivers with very low or very high flow rates during droughts or floods (at least for heavy rainfalls) and lead to deterioration of water quality. This is particularly true for heavy rain impacts on small watershed where runoff is a nonlinear, complex procedure applying the watershed's geomorphologic properties, such as topology, vegetation, soil type, and climatic factors i.e., precipitation, temperature, etc. (Wang et al., 2007; Jin et al., 2009).

One of the first studies performed in North American rivers regarding climate change impacts (warming) and water quality, anticipated a decreased oxygen-carrying capacity, a decreased volume for dilution of chemical inputs and the invasion by temperature-sensitive exotic species (Murdoch et al., 2000). 
Soil leaching following rainfall events in agricultural areas can lead to high levels of nitrate in surface waters used for potable water production and consequently in distributed waters (WHO, 2003). The main health risk associated with nitrate exposure is the methaemoglobinaemia, the infants being the susceptible population (WHO, 2003). Consequently, in order to protect the population, a water quality guideline for nitrate concentration has been set at $50 \mathrm{mg} / \mathrm{L}$ in France (Arrêté du 11 janvier, 2007). Furthermore, high levels of dissolved organic matter, suspended solids and pathogens are often measured in streams following rainfall events (Delpla et al., 2009; Hunter, 2003; van Vliet and Zwolsman, 2008; Zwolsman and van Bokhoven, 2007; Worrall and Burt, 2007). Most of the pathogens associated with suspended solids are responsible for water-borne diseases such as gastroenteritis (Beaudeau et al., $2001,2010)$. The water quality reference for TOC in France is set at $10 \mathrm{mg} / \mathrm{L}$ in raw waters both to protect human health and ensure treatment efficiency (Arrêté du 11 janvier, 2007).

The $\mathrm{C} / \mathrm{N}$ (here defined as total organic carbon/nitrogen-nitrate, $\mathrm{TOC} / \mathrm{N}-\mathrm{NO}_{3}$ ) ratio is a parameter commonly used to characterize soil organic matter and microbial activity which is less used for stream water (Meybeck, 1982; Taylor and Townsend, 2010). However, it could be used as an indicator to determine organic matter origin.

This study will mainly focus on the effects of flows on total organic carbon (TOC) and nitrate concentrations, including $\mathrm{C} / \mathrm{N}$ ratio, in regards to health risk assessment and SSWS adaptation. It is based on the interpretation of water quality data and flow rate measurements acquired from three small rivers in Brittany, France over a 27 years period. The three rivers considered have a rather stretched basin of low slope and a pluvial oceanic regime. Samples were collected from monitoring stations for small-scale water services (SSWSs) with a treatment plant drawing water directly from the river. Relationships between parameters are studied for the three sites.

\section{Material and methods}

\subsection{Description of the experimental field}

The characteristics of the three catchments (catchments A, B and $\mathrm{C}$ ) are described in Table 1.

The site $A$ is located downstream on a small river, approximately at a third of the way down its length $(87 \mathrm{~km})$. The river is used as a resource for drinking water production by a SSWS in Brittany, France. The land use is mainly agricultural ( $86 \%$ of area) with a large number of animal farms (cattle, pig, and poultry) and some agro-food industries including four slaughterhouses and four dairies. Over the five total counties located in the entire watershed, three showed an excess of the regulatory $\mathrm{N}$ production of $170 \mathrm{~kg} \mathrm{~N} \mathrm{ha}^{-1}$ (Agreste - DRAAF Bretagne, 2004, 2006; Council Directive, 1991) and three rural districts located at less than $20 \mathrm{~km}$ upstream of the abstraction point present the most important percentage of agricultural lands (from 97\% to 100\%) and could potentially present the greatest risk to water contamination (Corine Land Cover, 2010). The human density is approximately 50 inhabitants $\mathrm{km}^{-2}$. There are a few villages, and the main one owns a SSWS serving approximately 6000 people. Water samples were collected from the main sampling site of this SSWS which is the pump inlet of the treatment plant. The treatment process is after a conventional coagulation-settling step, followed by sand filtration, adsorption on activated carbon, and chlorine disinfection. This site is also characterized as a schist bedrock and soil with high silt content (67\%), inducing strong hydrological variations and high soil sensibility to erosion.

The second site (site B) is located approximately a third of the way downstream of a $101 \mathrm{~km}$ length river associated with a $710 \mathrm{~km}^{2}$ catchment area and characterized by a $7.1 \mathrm{~m}^{3} \mathrm{~s}^{-1}$ mean flow (calculated over 43 years). However, the discharge ranges from less than $0.9 \mathrm{~m}^{3} \mathrm{~s}^{-1}$ during droughts, to more than $28.8 \mathrm{~m}^{3} \mathrm{~s}^{-1}$ during floods. This watershed is characterized by an alternation of schist and granitic bedrock and pedology differs from the first site because soils contain a higher sand content (26\%) and a lower silt content (56\%) than site A. This site also faces strong agricultural pressures with $90 \%$ of the watershed covered by agricultural area and two counties located near the source among the seven covering the watershed, showing a N production exceeding the regulatory threshold of $170 \mathrm{~kg} \mathrm{~N} \mathrm{ha}^{-1}$. Cultivated areas represent approximately $65 \%$ of catchment area with 2700 farms mostly dedicated to cattle farming $\left(116 \mathrm{~km}^{-2}\right)$, pigs $\left(184 \mathrm{~km}^{-2}\right)$ and poultry $\left(2902 \mathrm{~km}^{-2}\right)$. Despite the minimal data available, it appears that there are lower industrial pressures at this site compared to the first site. However, at site B drinking water treatment is more complex as it includes ozonation and nitrate removal in addition to conventional treatment processes.

The third site ( site $\mathrm{C}$ ) is located approximately at the mid-point of a $41 \mathrm{~km}$ length river associated with a $147 \mathrm{~km}^{2}$ catchment area.

Table 1

Characteristics of the sites studied.

\begin{tabular}{|c|c|c|c|}
\hline & Site A & Site B & Site C \\
\hline River length (km) & 87 & 101 & 41 \\
\hline Upstream catchment area $\left(\mathrm{km}^{2}\right)$ & 468 & 710 & 147 \\
\hline Total catchment area $\left(\mathrm{km}^{2}\right)$ & 815 & 1220 & 170 \\
\hline Farms & 1300 & 2760 & 310 \\
\hline Cattle (number $\mathrm{km}^{-2}$ ) & 100.4 & 116.0 & 199.1 \\
\hline Pigs (number km-2) & 384.4 & 183.7 & \\
\hline Poultry (number km-2) & 10124.1 & 2902.1 & 1996.6 \\
\hline Geology & Schist bedrock & Schist and granitic bedrock & Granitic bedrock \\
\hline Mean soil particles composition ${ }^{\mathrm{b}}$ & Silt: $67 \%$, clay: $17 \%$, sand: $16 \%$ & Silt: $56 \%$, clay: $18 \%$, sand: $26 \%$ & Silt: $69 \%$, clay: $14 \%$, sand: $17 \%$ \\
\hline \multicolumn{4}{|l|}{ Hydrology ${ }^{\mathrm{c}}\left(\mathrm{m}^{3} \mathrm{~s}^{-1}\right)$} \\
\hline Mean flow $\left(\mathrm{m}^{3} \cdot \mathrm{s}^{-1}\right)$ & 3.1 & 7.1 & 1.9 \\
\hline Very Low Flow $\left(\mathrm{m}^{3} \cdot \mathrm{s}^{-1}\right)$ & $Q<0.4$ & $Q<0.9$ & $Q<0.3$ \\
\hline Low Flow $\left(\mathrm{m}^{3} \cdot \mathrm{s}^{-1}\right)$ & $0.4<Q<1.9$ & $0.9<Q<4.7$ & $0.3<Q<1.5$ \\
\hline Intermediate Flow $\left(\mathrm{m}^{3} \cdot \mathrm{s}^{-1}\right)$ & $1.9<Q<4.3$ & $4.7<Q<9.6$ & $1.5<Q<2.6$ \\
\hline
\end{tabular}

\footnotetext{
a Corine Land Cover database (Corine Land Cover, 2010), administrated by the French ministry of environment.

b French database of soil analysis (BDAT, 2011) administrated by the French National Institute for Agricultural Research (INRA).

c French hydrological database (Banque hydro, 2010) administrated by the French ministry of environment.
} 
With a discharge ranging from $0.3 \mathrm{~m}^{3} \mathrm{~s}^{-1}$ or less to $7.8 \mathrm{~m}^{3} \mathrm{~s}^{-1}$ or more, a mean flow of $1.9 \mathrm{~m}^{3} \mathrm{~s}^{-1}$ was calculated for 37 years of data. Unlike the other two sites, this site is characterized as a granitic bedrock. Soil composition is similar to the first site (silt: $69 \%$, clay: $14 \%$, sand: $17 \%$ ). This site is under substantial agricultural pressures with 310 farms, intensive livestock farming and an exceedance of the regulatory threshold of $170 \mathrm{~kg} \mathrm{~N} \mathrm{ha}^{-1}$ (Council Directive, 1991) in the two counties covering the watershed. Like the first site, the drinking water treatment processes include conventional coagulation-settling, sand filtration, and chlorination.

River hydrology for the three sites is presented in Table 1 . The data was collected for a period of 43 years, for sites A and B, and 37 years for site $C$. The dry discharge corresponds to the annual mean flow $\left(Q_{m_{43 y}}\right)$ that has $4 / 5$ probability of being exceeded each year. In the same way, the wet discharge corresponds to the annual mean flow that has $1 / 5$ probability of being exceeded each year. These values were used to sort out the daily flow rate $(Q)$ into five different classes: (i) very low flow, VLF (under $20 \%$ of dry discharge), (ii) low flow, LF (between VLF and dry discharge), (iii) intermediate flow, IF (between LF and wet discharge), (iv) high flow, HF (between IF and three times wet discharge) and (v) very high flow, VHF (greater than three times wet discharge).

\subsection{Raw data}

Water quality data were obtained from the French Ministry of Health through the national database SISE-EAUX. This database gathers the results of water quality analysis performed on drinking water resources and drinking water supply networks as part of the mandatory sanitary control program. Since no data was available prior to 1983 , the present study covers the period ranging from January 1983 to December 2009 (27 years) for the three sites. Parameters monitored were water temperature, $\mathrm{pH}$, conductivity, turbidity, oxidability, TOC and nitrate. Considering that on one hand the monitoring frequency (over 27 years) varies with the size of SSWS, and on the other hand, data set presents some missing values, the number of sampling vary from 150 to 266, depending on the site to be considered. Notice that the sampling was not designed to take into account the river hydrology, but was large enough to include storm and base flow conditions. More precisely, at each site $2 / 3$ of the samples were taken on the falling limb of the hydrograph and $1 / 3$ were taken on the rising limb. Overall, the greatest amount of data was related to site A, with 58 samples analyzed for turbidity and 230 for nitrate.

\subsection{Data pre-treatment}

Data conversions were needed for the coherence of the results of organic matter. Results were expressed only by permanganate oxidability in acidic conditions (OxA) at the beginning of the monitoring from 1983 to 1993, coupled with TOC after this date, and measured only as TOC after 1995. TOC values before 1993 were thus assessed by using a statistical relationship (determined from data during the period were both tests were being conducted) between these two parameters (TOC $=0 x A / 1.045, R^{2}=0.83, n=59$ ). Oxydability was analyzed by manual titration with permanganate (NF EN ISO 8467, 1995). TOC was determined by thermal oxidation coupled with infrared detection (Multi N/C 2100 Analytik Jena) following acidification with $\mathrm{HCl}$ (NF EN 1484, 1997). Nitrate concentration was expressed in $\mathrm{mg} \mathrm{L}^{-1}$ of $\mathrm{N}-\mathrm{NO}_{3}$. Nitrate was determined after a filtration through $0.45 \mu \mathrm{m}$ HAWP nitrocellulose filter papers (Millipore) with a continuous flux analyzer according to standard method (NF EN ISO 13395, 1996). For these analyses, the samples were stored at $4{ }^{\circ} \mathrm{C}$. In the present study, the mean flow calculated from the dataset was different from the one given by the French hydrological database. The daily flow rates $(Q)$ were shown to obey a log-normal distribution. Consequently, in order to avoid a huge dispersion of plots and make graphs readable, the normalized flow rates $\left(Q / Q_{m}\right)$ and their logarithmic values $\log \left(Q / Q_{m}\right)$ were also considered. Moreover, normalized fluxes were calculated as the product of the concentrations and the corresponding normalized flow rates $\left(Q / Q_{m}\right)$. Correlation matrix calculations were created using the Pearson correlation test. Finally, correlation and linear and non-linear adjustments were calculated with Statistica V6, from StatSoft Inc.

\section{Results and discussion}

The first step was to compare the parameters through the calculation of correlation coefficients (Table 2).

The first observation is that more than $3 / 4$ of the correlation coefficients were statistically significant, considering the related $p$-values. All parameters show fair correlations with log of normalized values of river discharges, and lower correlations with normalized flow rate, except for turbidity and TOC which have a similar behavior and are linked together and to normalized flow rate. Conductivity and $\mathrm{pH}$ are linked to other parameters except turbidity for conductivity and TOC for $\mathrm{pH}$. The highest correlations with flow rate are observed for conductivity and $\mathrm{pH}$ and are plotted in Fig. 1.

Thus TOC values are not well correlated with water temperature in this case, which is contrary to previous studies showing that TOC load of river is not only a rainfall driven but also a temperature driven biological process (Ouyang, 2003). Notice that correlation coefficients are either positive or negative depending on the parameters. Considering the importance of TOC and nitrate concentrations for the assessment of water quality and their variation with flowrate particularly in the context of heavy rain or droughts (Delpla et al., 2011a) it was decided to focus on the impact of river flow rate on water quality parameters. TOC and nitrate were also chosen for the high concentrations found locally (GIP Bretagne Environnement, 2011) and their potential health risks (Bull et al., 1995; Katsoyiannis and Samara, 2007).

Table 2

Pearson correlation between parameters for the three sites (number of samples is in brackets).

\begin{tabular}{|c|c|c|c|c|c|c|c|}
\hline & $\log \left(Q / Q_{m}\right)$ & $Q / Q_{m}$ & $\begin{array}{l}\text { Water temperature } \\
\left({ }^{\circ} \mathrm{C}\right)\end{array}$ & Turbidity (NFU) & $\begin{array}{l}\text { Conductivity at } \\
20^{\circ} \mathrm{C}\left(\mu \mathrm{S} \mathrm{cm}^{-1}\right)\end{array}$ & $\mathrm{pH}$ & $\mathrm{TOC}\left(\mathrm{mg} \mathrm{L}^{-1}\right)$ \\
\hline$Q / Q_{m}$ & $0.67(n=579)$ & & & & & & \\
\hline Water temperature $\left({ }^{\circ} \mathrm{C}\right)$ & $-0.52(n=340)$ & $-0.30(n=340)$ & & & & & \\
\hline Turbidity (NFU) & $0.35(n=142)$ & $0.47(n=142)$ & $-0.13(n=157)$ & & & & \\
\hline Conductivity at $20^{\circ} \mathrm{C}\left(\mu \mathrm{S} \mathrm{cm}^{-1}\right)$ & $-0.70(n=215)$ & $-0.28(n=215)$ & $0.23(n=257)$ & $-0.07(n=105)$ & & & \\
\hline $\mathrm{pH}$ & $-0.65(n=354)$ & $-0.30(n=354)$ & $0.47(n=402)$ & $-0.04(n=161)$ & $0.57(n=270)$ & & \\
\hline TOC $\left(\mathrm{mg} \mathrm{L}^{-1}\right)$ & $-0.01(n=291)$ & $0.37(n=291)$ & $0.15(n=318)$ & $0.41(n=147)$ & $0.27(n=215)$ & $0.07(n=330)$ & \\
\hline $\mathrm{N}-\mathrm{NO}_{3}\left(\mathrm{mg} \mathrm{L}^{-1}\right)$ & $0.50(n=512)$ & $0.09(n=512)$ & $-0.39(n=390)$ & $-0.09(n=157)$ & $-0.48(n=265)$ & $-0.37(n=409)$ & $-0.42(n=319)$ \\
\hline
\end{tabular}

In bold: statistically significant values $(p<0.05)$. 


\subsection{Variation of organic carbon and nitrate with river flow}

Firstly, the hydrology follows a seasonal behavior with higher flows from December to February and lower flows from July to September consistent with previous studies conducted in temperate areas (Attrill and Power, 2000). The seasonal values of TOC and nitrate $\left(\mathrm{N}-\mathrm{NO}_{3}\right)$, calculated over the 27 -year period are reported in Fig. 2.

As expected, after the above correlation study, nitrate concentration and the flow rate of the rivers, followed the same yearly pattern, with the lowest values occurring during summer (from July to September) and highest values during winter (from January to March). However, these seasonal trends should be viewed with caution as these are linked to high pressure from agriculture, with the application of manure or slurries to the fields each year during mid-winter and the start of summer from the year 2000. This may have contributed to the elevated nitrate and TOC concentrations in the river water.

\subsection{Distribution of organic carbon and nitrate according to river flow}

The relationship between TOC and nitrate concentration with flow rate $\left(\log \left(Q / Q_{m}\right)\right)$ is shown in Fig. 3, which also considers the French limits of quality for drinking water resources, $10 \mathrm{mg} \mathrm{L}^{-1}$
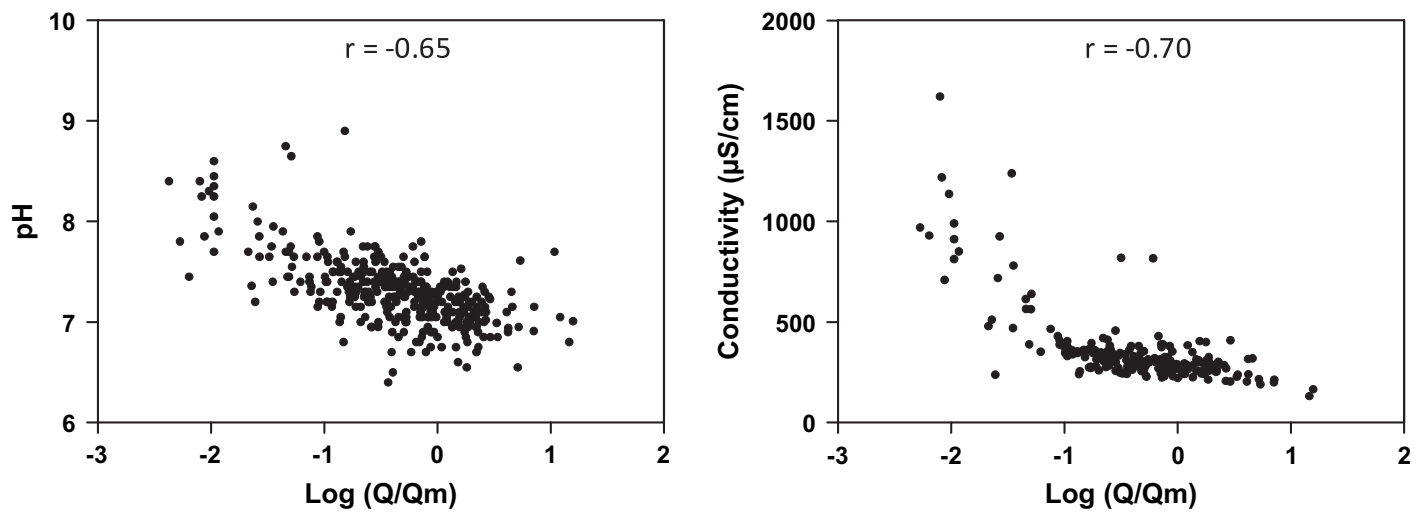

Fig. 1. Variation of $\mathrm{pH}$ and conductivity with log of normalized flow rate for the three sites. Pearson correlation coefficients ( $r$ ) are given for each plot.
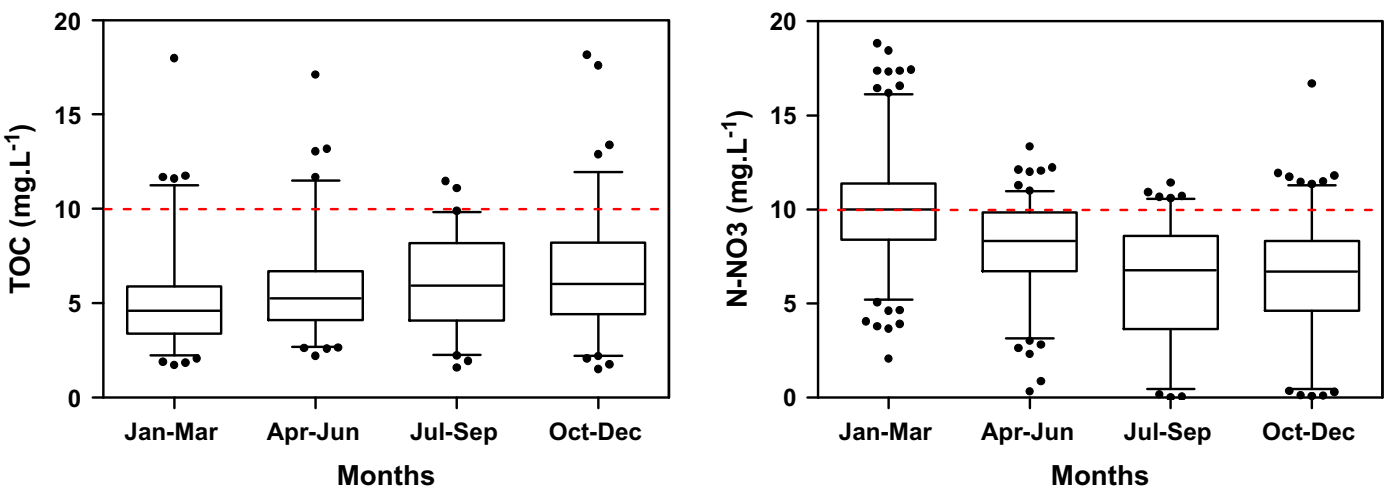

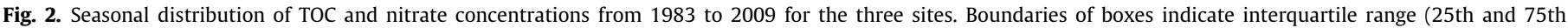
percentiles) and median values (midline), whiskers indicate 5th and 95th percentiles and symbols indicate maximum values.
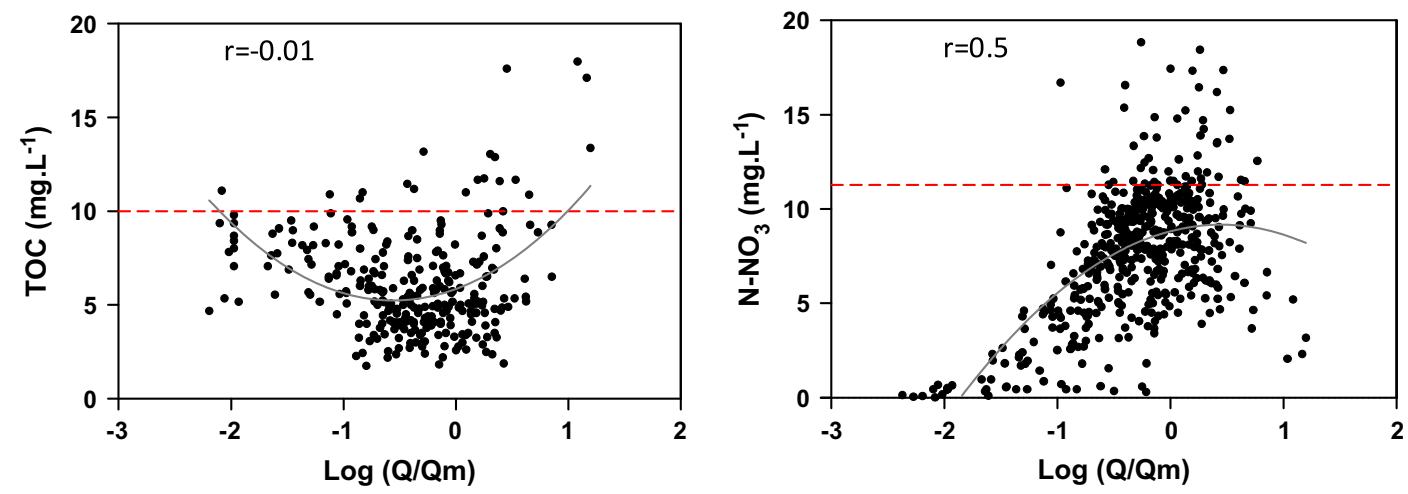

Fig. 3. Relation between TOC and nitrate concentrations with flow rate $\left(\log \left(Q / Q_{m}\right)\right)$ for the three sites. Pearson correlation coefficients $(r)$ are given for each plot. 
for TOC and $11.3 \mathrm{mg} \mathrm{L}^{-1} \mathrm{~N}-\mathrm{NO}_{3}$ (i.e. $50 \mathrm{mg} \mathrm{NO}_{3} \mathrm{~L}^{-1}$ ). Two evolution schemes are observed for TOC and nitrate concentrations. TOC concentration tends to decrease when $\log \left(Q / Q_{m}\right)$ increases from -2 to 0 (corresponding to $Q$ ranging from $1 \%$ to $100 \%$ of $Q_{m}$ ) and increase for $\log \left(Q / Q_{m}\right)$ greater than 0 (corresponding to $Q$ higher than $100 \%$ of $Q_{m}$ ). Contrary to TOC, nitrate concentration rises from 0 to more than $11.3 \mathrm{mg} \mathrm{L}^{-1}$ for $\log \left(\mathrm{Q} / \mathrm{Qm}_{\mathrm{m}}\right)$ ranging from -2 to 0 and decrease for higher values. Even if the majority of the points stay below quality limit for nitrate, the highest values $\left(18.9 \mathrm{mg} \mathrm{L}^{-1}\right)$ are encountered for mean flow rates. Concerning instances of TOC concentrations exceeding $10 \mathrm{mg} \mathrm{L}^{-1}$, some samples correspond to low flows, but for the highest values of TOC the samples correspond to flows upper than the mean flow rate. Overall, the relationship between nitrate and flow rate $(R=0.53)$ was stronger than TOC and flow rate $(R=0.12$, see Table 2$)$.

The wide variation in TOC and nitrate concentrations in relation to river flow make it difficult to quickly identify the hydrological conditions that would cause a increase in the number of times that the water quality guidelines would be exceeded. TOC and nitrate results were sorted into five main flow rate classes, previously described in Table 1 . This shows the conditions for a higher vulnerability of surface water quality with respect to health risk assessment (Fig. 4). The box plots TOC graph highlights that there is a greater risk of exceeding the French limit of quality for drinking water resources when the flow rate is high (floods). For nitrate, the risk of exceeding the limit seems to be lower. Overall, the highest probability for nitrate exceedances occurs at flow rates greater than the mean value with the risk decreasing for higher flows.

\subsection{Variation of TOC and nitrate fluxes with flow rate}

The evolution of fluxes is quite different between TOC and nitrate. TOC flux (FTOC) increases regularly, while nitrate flux (FN$\mathrm{NO}_{3}$ ) remains relatively constant for very high flows (Fig. 5a and b).

Polynomial adjustment lead to good correlations $\left(R^{2}=0.94\right.$ for FTOC and 0.83 for $\mathrm{FN}^{-\mathrm{NO}_{3}}$ ), but variation of both fluxes can be considered as partly linear for flow rates less than $3 \mathrm{Q} / \mathrm{Q}_{m}$ (see zoom in Fig. 5b).

\subsection{Variation of organic carbon-nitrate relationship with river flow}

TOC and nitrate concentrations evolution with log of normalized flow rate is quite different (Fig. 3). Consequently, the study of $\mathrm{C} / \mathrm{N}$ ratio calculated from these parameters could provide some interesting findings about the origin of organic matter (Meybeck, 1982) and therefore on its treatability. Moreover, according to Taylor and Townsend (2010), there exist some relationships between nitrate and organic carbon (dissolved or particulate) along a hydrologic continuum from soils to streams and lakes.

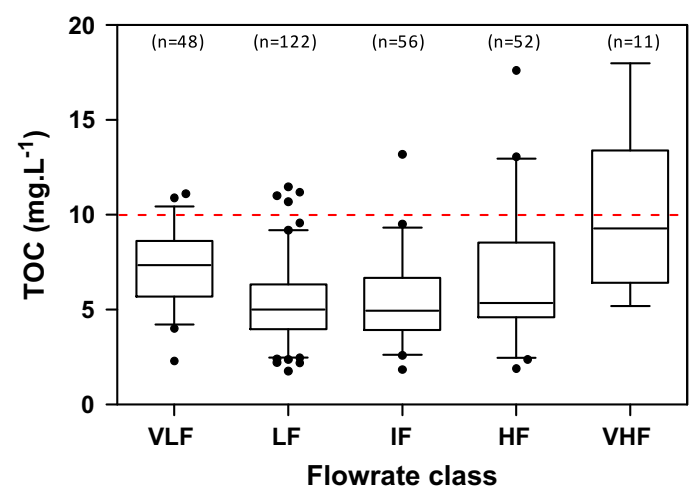

In order to clearly reveal the potential impact of extreme flows, Fig. 6 displays the evolution of the $\mathrm{C} / \mathrm{N}\left(\mathrm{TOC} / \mathrm{N}-\mathrm{NO}_{3}\right)$ concentrations ratios, with river flows represented by the inverse of $\log (Q /$ $\left.Q_{m}\right)$. This choice, which places very low or very high flow rates near the origin, shows that the corresponding $\mathrm{C} / \mathrm{N}$ ratios increase strongly when $1 / \log \left(Q / Q_{m}\right)$ tends towards 0 . More precisely, this is observed for $-1<1 / \log \left(Q / Q_{m}\right)<1$ corresponding to $Q<0.1 Q_{m}$ or $Q>10 Q_{m}$. However, there is a difference between very low flows corresponding to droughts for which $\mathrm{C} / \mathrm{N}$ values rise up to 50 , and very high flows corresponding to floods with $\mathrm{C} / \mathrm{N}$ values lower than 10. Between these values of extreme flow rates, i.e. for values around the mean flow rate, the $\mathrm{C} / \mathrm{N}$ ratio is very low and close to one.

\section{Discussion}

\section{1. $C / N$ variation}

Among the above results, the variation of $\mathrm{C} / \mathrm{N}\left(\mathrm{TOC} / \mathrm{N}-\mathrm{NO}_{3}\right)$ with river flows (Fig. 6) must be highlighted. For the majority of low flows, $\mathrm{C} / \mathrm{N}$ is quite low, around $1-1.3$, in accordance with Kim et al. (2007). For extreme flows, the $\mathrm{C} / \mathrm{N}$ ratio increases to reach very high values (around 50 ), with a difference between the maxima of $\mathrm{C} / \mathrm{N}$ corresponding to low and high flows, the latter giving lower maxima (less than 10). Similarly, Wysocki et al. (2006) showed that $\mathrm{C} / \mathrm{N}$ ratios are higher during low flows than during high flows. The data analysis shows that $\mathrm{C} / \mathrm{N}$ increase is observed for flows lower or greater than $10 \%$ or $1000 \%$ respectively of the mean flow. Considering these results and the ones of Delpla et al. (2011a), the following explanations can be proposed: (i) For low flows, occurring mostly in summer, nitrate is assimilated by the biomass (phytoplankton and macrophytes) (van Vliet and Zwolsman, 2008) and moreover supply from soil leaching is reduced during the dry season (Delpla et al., 2011a; van Vliet and Zwolsman, 2008). The biomass growth leads to an increase in TOC concentration observed for low flows. (ii) For high flows, generally in winter, $\mathrm{C} / \mathrm{N}$ is controlled by surface runoff and dilution. The importance of organic carbon as soluble, colloidal, and particulate forms exportation by surface runoff during rainy events, is depending on physico-chemical parameters of soil (nature, slope, moisture, etc.), rain (intensity, duration) (Delpla et al., 2011b; Jacinthe et al., 2004) and land use (Tejada and Gonzalez, 2008). For nitrate concentration, the value remains always not negligible despite dilution because an higher supply by soil leaching in winter (at least for the area studied) (Fig. 2). Finally, these $\mathrm{C} / \mathrm{N}$ values are close to that of organic soils reflecting a high supply of exogenous organic constituents (Meybeck, 1982).

In case of agricultural area amended by animal waste or biosolids as fertilizers, organic carbon in runoff is mostly related to

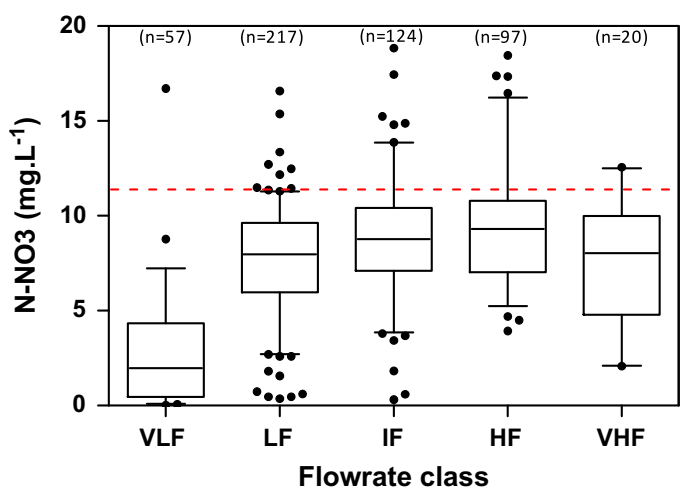

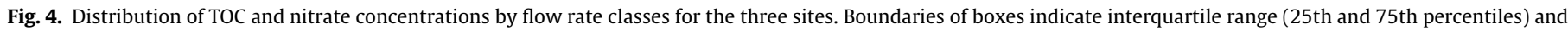

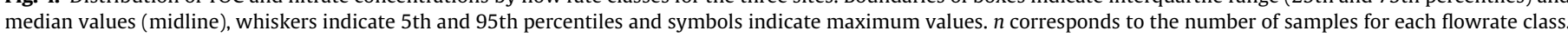


(a)
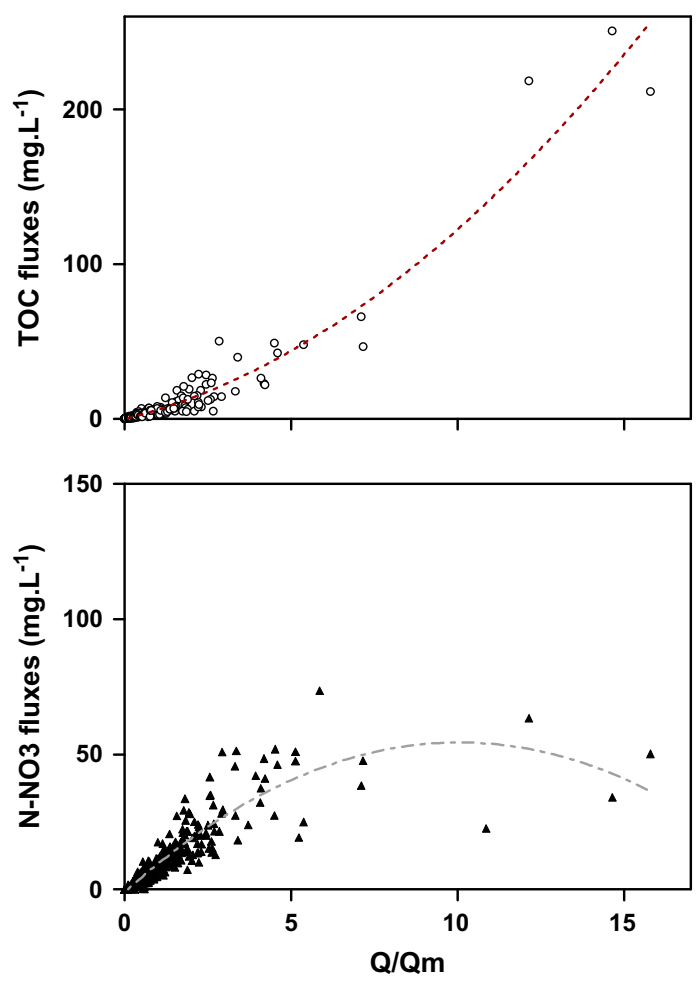

(b)
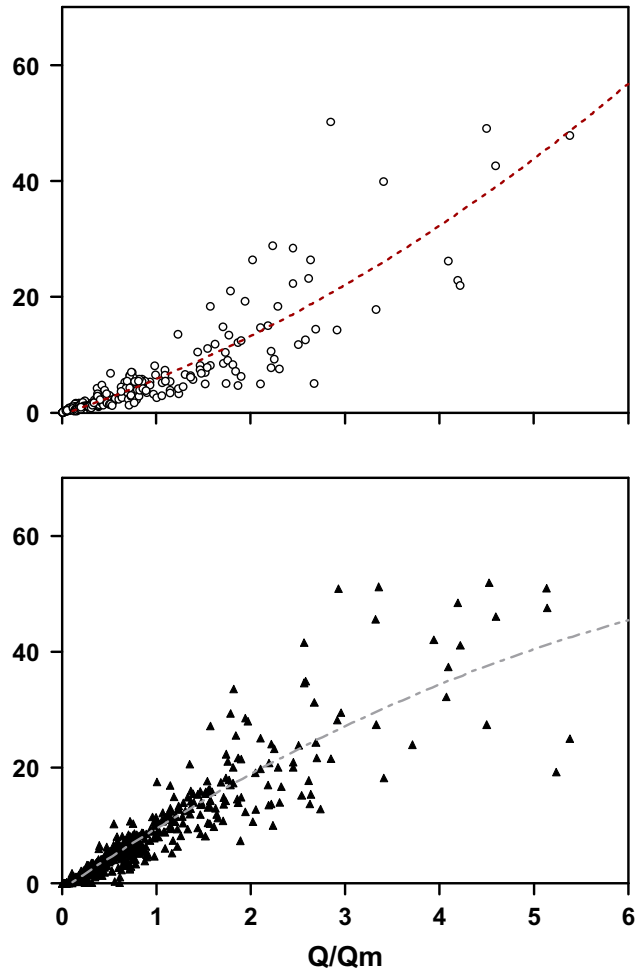

Fig. 5. (a) Impact of normalized flow rate on $\mathrm{TOC}$ and $\mathrm{N}-\mathrm{NO}_{3}$ fluxes for the three sites and (b) zoom.

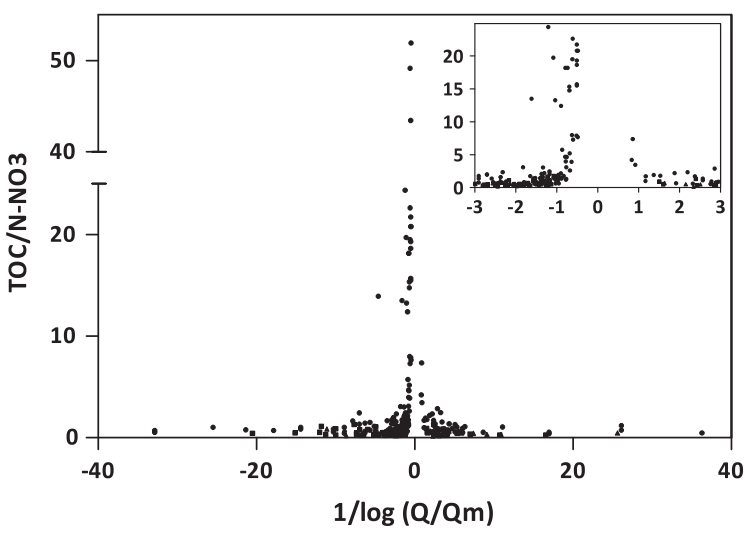

Fig. 6. Impact of discharge on $\mathrm{C} / \mathrm{N}$ ratio variation for the three sites.

manure or slurry, particularly after spreading (Haynes and Naidu, 1998; Schulten and Leinweber, 1991). Nitrate flux depends on different mechanisms and mainly the transfer from the aqueous form or groundwater if any and a dilution with rain.

Finally, studies undertaken on larger rivers indicate that lower nitrate concentrations are associated with lower river flows (Attrill and Power, 2000; van Vliet and Zwolsman, 2008). Thus the interpretation of nitrate sources based on discharge and nitrate concentration relationship is still uncertain because of the difficulty in interpreting nitrate sources.

\subsection{Towards a generalization}

After the theory of $\mathrm{C} / \mathrm{N}$ variation with extreme flow rates is discussed, it is important to compare the results between the three sites studied ( $A, B$ and $C$ ). All the sites follow the same patterns for concentration, fluxes and $\mathrm{C} / \mathrm{N}$ variations when the relationship between TOC and nitrate with flow rates were examined. However, because the dynamic of flows were less important at sites $B$ and $C$ as compared to site $\mathrm{A}$, a decrease in nitrate concentration or fluxes was not observed. Flow rates of rivers located in granitic bedrocks catchments generally undergo less variability than those located on schist bedrock (Mérot, 2003) and could explain the lowest variability in flow rates for site C. Despite this, the relationship between TOC and nitrate fluxes and flow rates are linear for the three sites, with strong correlation coefficients (Table 3).

For nitrate flux, the slope values are very close for the three sites (respectively 8.92, 9.59 and 9.26 for A, B and C). These trends could be strengthened by considering land use practices, which at present include two amendment periods (during the end of winter and summer beginning) corresponding to nitrate supply. More generally, these similarities could be explained by the controlled agricultural practices all year long, which results in a dynamic production and release of nitrate nearly constant and limited (Oeurng et al., 2010).

Table 3

Relations between TOC and nitrate normalized fluxes $(y=a x+b)$ with flow rates for the three sites.

\begin{tabular}{lllllr}
\hline Site & Flux & $a$ & $b$ & $R$ & \multicolumn{1}{l}{$n$} \\
\hline $\mathrm{A}^{\mathrm{a}}$ & TOC & 9.01 & -0.96 & 0.90 & 164 \\
& Nitrate & 8.92 & -0.54 & 0.91 & 233 \\
$\mathrm{~B}$ & TOC & 6.44 & 1.07 & 0.91 & 84 \\
& Nitrate & 9.59 & -0.18 & 0.90 & 183 \\
$\mathrm{C}$ & TOC & 4.88 & -0.65 & 0.90 & 34 \\
& Nitrate & 9.26 & 0.21 & 0.95 & 92
\end{tabular}

a For site A, fluxes are calculated for flow rates $<500 \%$ of $Q_{m}$. 
For TOC flux, the slope values are different for the three sites, (respectively $9.01,6.44$ and 4.88 for A, B and C). These differences could be explained by several parameters which influence organic matter concentration, which include the geology and pedology. For example, clod disaggregation under raindrop impacts result in a formation of surface crusts (Le Bissonnais et al., 1998), reducing the soil infiltration rate and inducing erosion by increasing runoff (Le Bissonnais et al., 1995) and so increasing organic matter flux. In fact, the soils on the site A watershed could be particularly prone to crusting (Delpla et al., 2011b). Moreover, these observations might be consistent with the presence of two pools of organic matter: allochtonous large-size colloids formed by lixiviation from upper soil horizons (Kim et al., 2007) and autochthonous (aquatic) small molecular-size substances, probably linked to bacterial and phytoplankton exudates. The proportion of both possible pools is highly dependent on the season. Allochtonous input of organic carbon strongly increases during the spring flood, whereas the bacterial/plankton exudates of the second pool of organic matter are seasonally variable reflecting both light and temperature changes in photosynthesis/respiration.

Finally, our findings must be considered as a first step in simple modelling for TOC and nitrate fluxes, which are complementary to powerful tools like deterministic models (Wriedt and Rode, 2006), which certainly must be checked at other sites with different environmental and socio-economic conditions.

\subsection{Impact on small scale water services}

Floods and droughts, which are likely to increase with climate change, may impact the quality of water resources used for drinking water production by direct effects of dilution or concentration of dissolved substances (Delpla et al., 2009). Therefore, as stated in a recent World Health Organisation (WHO) report (WHO, 2010), these extreme weather events could affect the efficiency of drinking water treatment processes and the stability of drinking water quality in distribution. These concerns are important for smallscale water services in rural areas, which are particularly sensitive because of difficulties to adapt treatment to such variations. Considering that a large part of the population living in rural areas do not have access to improved drinking-water sources, e.g. 16 million people in Europe (WHO and DFID, 2010 ${ }^{1}$ ), small-scale water supplies producing tap water from surface resources are facing several challenges including their regulatory environment, administration, management, operational or available techniques, as well as dwindling personnel and financial resources (WHO, 2010).

\subsection{Hydrological limits for monitoring relevance}

The previous results suppose homogeneous conditions in the section of rivers were samples were taken in order to be able to monitor a representative state of water quality. Among factors of variability, small rivers like the ones considered in the present studies are characterized by various hydromorphological characteristics (slope, banks, bed, etc.) and the presence of several tributaries on the related watersheds may induce a local distribution of pollutants as nitrates and organic carbon. For example, the influence of the bottom topography (Thomas and Linden, 1998; Cenedese and Linden, 2002) or the lateral mixing of pollutants when the tributary channel is shallower than the main channel (Biron et al., 2004) may lead to a sectional gradient of water quality particularly in the downstream vicinity of a confluence. Moreover, flow mixing rates downstream confluences is depending on bed roughness and nature (Parsons et al., 2007), and bed form geome-

\footnotetext{
${ }^{1}$ Department For International Development.
}

tries and nature also explains sediment deposition/transportation with current (Mianaei and Keshavarzi, 2010). Depending of the development of river, water quality may vary with the presence of a dam for example, reducing both sediments transportation and fauna distribution of derived zooplankton (Takao et al., 2008). River branching related to watershed topography, and its consequences on flowrate (Yousefi and Ghiassi, 2011) can also be considered local factor of water quality variation. Finally, floods frequency increase is a strong factor of water quality variation with pollutants and solids transportation and modification of flow routing (He et al., 2007).

\section{Conclusion}

To date, except a couple of studies (Delpla et al., 2009; van Vliet and Zwolsman, 2008), very few papers describe the potential effects of climate change and particularly the hydrologic regime of river on water quality. The present study provides original results on the variation of organic carbon - nitrate relationship with this hydrologic regime, covering a relatively long period ranging from January 1983 to December 2009 (27 years). This study shows the importance of the extreme hydrologic regime particularly for the very low $\left(Q<10 \%\right.$ of $\left.Q_{m}\right)$ flows on $\mathrm{C} / \mathrm{N}\left(\mathrm{TOC} / \mathrm{N}-\mathrm{NO}_{3}\right)$ ratio. For the dry period, especially in summer, with low water levels, the $\mathrm{C} / \mathrm{N}$ ratio increase could be explained mainly by the decrease in nitrate concentration. This decrease is mainly justified by the in-stream biomass consumption, its reduced supply due to the high mobility of this substance and plant mobilization during dry periods. However, a public health risk assessment is more sensible if the water quality is considered in term of flux rather than concentration. This study shows that, for very high flow ( $Q>500 \%$ of $Q_{m}$ ), the TOC flux increase and the nitrate flux decrease. Thus the TOC flux becomes a major concern for the SSWS without adapted waterworks. Such findings should be useful for the administrations in charge of sanitary control but also for those in charge of drinking water production. In fact, the present conclusions promote the adaptation of drinking water treatment based on the hydrological conditions. However, further research should be undertaken to validate and check our findings for other conditions, taking into account the local variability of water quality in river sections, and to integrate other water quality parameters like microbiological contamination or concentration of micropollutants and organic carbon under soluble, colloidal and particulate forms into an accurate statistical model for water quality prediction and health risk assessment.

\section{Acknowledgements}

The authors sincerely thanks the French Agence Régionale de Santé (ARS) of Brittany and the Ministère de l'Ecologie, du Développement Durable, des Transports et du Logement (MEDDTL) for the data provided and are grateful to Darryl Jones, Ph.D. student at the University of Arizona (USA), for his assistance in editing. This work was partially funded by the French National Agency of Sanitary Security (ANSES) under the first ERA-EnvHealth call (FP7-ENV2007-CSA-1.2.3-01).

\section{References}

Agreste - DRAAF Bretagne, 2004. Fichiers administratifs PAC et BDNI, recensemen avicole.

Agreste - DRAAF Bretagne, 2006. Fichiers administratifs PAC et BDNI, recensement des sites porcins.

Arrêté du 11 janvier 2007 relatif aux limites et références de qualité des eaux brutes et des eaux destinées à la consommation humaine mentionnées aux articles $\mathrm{R}$ 1321-2, R. 1321-3, R. 1321-7 et R. 1321-38 du code de la santé publique. Journal Officiel, n`31 du 6 février 2007, page 2180, texte no. 17 . 
Attrill, M.J., Power, M., 2000. Modelling the effect of drought on estuarine water quality. Water Res. 34, 1584-1594.

Banque hydro, 2010. Online French hydrological database accessible at <http:// www.hydro.eaufrance.fr/> (accessed 10.12.10).

BDAT, 2011. Online French Soil analysis database accessible at http:// acklins.orleans.inra.fr/geosol/index.php (accessed 03.02.11).

Beaudeau, P., Leboulanger, T., Lacroix, M., Hanneton, S., Wang, H.Q., 2001. Forecasting of turbid floods in a coastal, chalk karstic drain using an artificial neural network. Ground Water 39 (1), 109-118.

Beaudeau, P., Valdes, D., Mouly, D., Stempfelet, M., Seux, R., 2010. Natural and technical factors in faecal contamination incidents of drinking water in small distribution networks, France, 2003-2004: a geographical study. J. Water Health 08 (1), 20-34

Biron, P.M., Ramamurthy, A.S., Han, S., 2004. Three-dimensional numerical modeling of mixing at river confluences. J. Hydraul. Eng. 130 (3), 243-253.

Bull, R.J., Birnbaum, L.S., Cantor, K.P., Rose, J.B., Butterworth, B.B., Pegram, R., Tuomisto, J., 1995. Water chlorination: essential process or cancer hazard? Fund. Appl. Toxicol. 28, 155-166.

Cenedese, C., Linden, P.F., 2002. Stability of a buoyancy-driven coastal current at the shelf break. J. Fluid Mech. 452, 97-121.

Corine Land Cover, 2010. Online French geographical database accessible at <http:/| www.stats.environnement.developpement-durable.gouv.fr/bases-de-donnees/ occupation-des-sols-corine-land-cover $>$ (accessed 10.12.10)

Council Directive 91/676/EEC of 12 December 1991 Concerning the Protection of Waters against Pollution caused by Nitrates from Agricultural Sources.

Delpla, I., Jung, A.V., Baurès, E., Clément, M., Thomas, O., 2009. Impacts of climate change on surface water quality in relation to drinking water production. Environ. Int. 35, 1225-1233.

Delpla, I., Baurès, E., Jung, A.V., Clément, M., Thomas, O., 2011a. Issues of drinking water quality of small scale water services towards climate change. Water Sci. Technol. 63, 227-232.

Delpla, I., Baurès, E., Jung, A.-V., Thomas, O., 2011b. Impacts of rainfall events on runoff water quality in an agricultural environment in temperate areas. Sci. Total Environ. 409, 1683-1688

GIP (Groupement d'Interêt Public). Bretagne environnement, accessible at <http:// www.observatoire-eau-bretagne.fr> (accessed 01.10.11).

Haynes, R.J., Naidu, R., 1998. Influence of lime. Fertilizer and manure applications on soil organic matter content and soil physical conditions: a review. Nutr. Cycl. Agroecosyst. 51, 123-137.

He, H.M., Zhou, J., Yu, Q., Tian, Y.Q., Chen, R.F., 2007. Flood frequency and routing processes at a confluence of the Middle yellow river in China. River Res. Applic. 23 (4), 407-427.

Hunter, P.R., 2003. Climate change and waterborne and vector-borne disease. J. Appl. Microbiol. 94, 37S-46S.

Jacinthe, P.-A., Lal, R., Owens, L.B., Hothem, D.L., 2004. Transport of labile carbon in runoff as affected by land use and rainfall characteristics. Soil Till Res. 77, 111123.

Jin, K., Cornelis, W.M., Gabriels, D., Baert, M., Wu, H.J., Schiettecatte, W., Cai, D.X., De Neve, S., Jin, J.Y., Hartmann, R., Hofman, G., 2009. Residue cover and rainfall intensity effects on runoff soil organic carbon losses. Catena 78, 81-86.

Katsoyiannis, A., Samara, C., 2007. The fate of dissolved organic carbon (DOC) in the wastewater treatment process and its importance in the removal of wastewater contaminants. Environ. Sci. Pollut. Res. Int. 14 (5), 284-292.

Kim, J.-H., Ludwig, W., Schouten, S., Kerherve, P., Herfort, L., Bonnin, J., Sinninghe Damste, J.S., 2007. Impact of flood events on the transport of terrestrial organic matter to the ocean: a study of the Têt River (SW France) using the BIT index. Org. Geochem. 38, 1593-1606.

Le Bissonnais, Y., Renaux, B., Delouche, H., 1995. Interactions between soil properties and moisture content in crust formation, runoff and interrill erosion from tilled loess soils. Catena 25, 33-46.

Le Bissonnais, Y., Benkhadra, H., Chaplot, V., Fox, D., King, D., Daroussin, J., 1998. Crusting, runoff and sheet erosion on silty loamy soils at various scales and upscaling from $\mathrm{m}^{2}$ to small catchments. Soil Till. Res. 46, 69-80.

Mérot, P., 2003. Small rural catchment functioning in the framework of floods and rainfall-runoff events. La Houille Blanche 6, 1-9.

Meybeck, M., 1982. Carbon, nitrogen and phosphorus transport by world rivers. Am. J. Sci. 282, 401-450.
Mianaei, S.J., Keshavarzi, A.R., 2010. Study of near bed stochastic turbulence and sediment entrainment over the ripples at the bed of open channel using image processing technique. Stoch. Environ. Res. Risk Assess. 24, 591-598.

Murdoch, P.S., Baron, J.S., Miller, T.L., 2000. Potential effects of climate change on surface-water quality in North America. J. Am. Water Resour. Assoc. 36, 347366.

NF EN 1484, Juillet 1997. Analyse de l'eau. Lignes directrices pour le dosage du Carbone Organique Total et du Carbone Organique Dissous.

NF EN ISO 13395, Octobre 1996. Détermination de l'azote nitreux et de l'azote nitrique et de la somme des deux par analyse en flux continu et détection spectrométrique.

NF EN ISO 8467, Juillet 1995. Qualité de l'eau. Détermination de l'indice permanganate.

Oeurng, C., Sauvage, S., Sánchez-Pérez, J.-M., 2010. Temporal variability of nitrate transport through hydrological response during flood events within a large agricultural catchment in south-west France. Sci. Total Environ. 409, $140-149$.

Ouyang, Y., 2003. Simulating dynamic load of naturally occurring TOC from watershed into a river. Water Res. 37, 823-832.

Parsons, D.R., Best, J.L., Lane, S.N., Orfeo, O., Hardy, R.J., Kostaschuk, R., 2007. Form roughness and the absence of secondary flow in a large confluence-diffluence, Rio Paraná, Argentina. Earth Surf. Process. Landforms 32, 155-162.

Schulten, H.-R., Leinweber, P., 1991. Influence of long-term fertilization with farmyard manure on soil organic matter: characteristics of particle-size fractions. Biol. Fert. Soils 12, 81-88.

Takao, A., Kawaguchi, Y., Minagawa, T., Kayaba, Y., Morimoto, Y., 2008. The relationships between benthic macroinvertebrates and biotic and abiotic environmental characteristics downstream of the Yahagi dam, central japan, and the state change caused by inflow from a tributary. River Res. Applic. 24 (5), 580-597.

Taylor, P.G., Townsend, A.R., 2010. Stoichiometric control of organic carbon-nitrate relationships from soils to the sea. Nature 464, 1178-1181.

Tejada, M., Gonzalez, J.L., 2008. Influence of two organic amendments on the soil physical properties, soil losses, sediments and runoff water quality. Geoderma $145,325-334$

Thomas, P.J., Linden, P.F., 1998. A bi-modal structure imposed on gravity driven boundary currents in rotating systems by effects of the bottom topography. Exp. Fluids 25, 388-391.

van Vliet, M.T.H., Zwolsman, J.J.G., 2008. Impact of summer droughts on the water quality of the Meuse river. J. Hydrol. 353, 1-17.

Wang, X.K., Lu, W.Z., Cao, S.Y., Fang, D., 2007. Using time delay neural network combined with genetic algorithm to predict runoff level of Linshan watershed, Sichuan, China. J. Hydrol. Eng.-ASCE 12 (2), 231-236.

World Health Organization (WHO), 2003. Nitrate and nitrite in drinking-water. Background Document for Preparation of WHO Guidelines for Drinking-Water Quality. Geneva, World Health, Organization (WHO/SDE/WSH/03.04/56).

World Health Organization (WHO), 2010. Guidance on water supply and sanitation in extreme weather events. In: Sinisi, L., Aertgeerts, R. (Eds.), World Health Organization, Geneva, Switzerland, $105 \mathrm{pp}$.

World Health Organization (WHO) and Department For International Development (DFID), 2010. Vision 2030: the resilience of water supply and sanitation in the face of climate change at <http://www.who.int/water_sanitation_health/ publications/9789241598422_cdrom/en/index.html> (accessed 05.01.11).

Worrall, F., Burt, T.P., 2007. Trends in DOC concentration in Great Britain. J. Hydrol 346, 81-92.

Wriedt, G., Rode, M., 2006. Modelling nitrate transport and turnover in a lowland catchment system. J. Hydrol. 328, 157-176.

Wysocki, L.A., Bianchi, T.S., Powell, R.T., Reuss, N., 2006. Spatial variability in the coupling of organic carbon, nutrients, and phytoplankton pigments in surface waters and sediments of the Mississippi River plume. Estuar. Coast. Shelf Sci. 69, 47-63.

Yousefi, S., Ghiassi, R., 2011. Modeling and analyzing flow diversion in branching channels with symmetric geometry. River Res. Applic. 27 (7), 805-813.

Zwolsman, J.J.G., van Bokhoven, A.J., 2007. Impact of summer droughts on water quality of the Rhine River - a preview of climate change? Water Sci. Technol. 56, 44-55. 